Original Research Paper

\title{
Antioxidant and Antiproliferative Potential of Acacia auriculiformis Methanol Leaves Extract Against Breast Cancer Cell Model
}

\author{
Triska Desi Sundari ${ }^{1} \&$ Nastiti Wijayanti ${ }^{2 *}$ \\ ${ }^{1}$ Magister Program in Biology, Departement of Tropical Biology, Faculty of Biology, Universitas \\ Gadjah Mada. Jl. Teknika Selatan, Sekip Utara, Yogyakarta 55281, Indonesia; \\ ${ }^{2}$ Animal Physiology Laboratory, Departement of Tropical Biology, Faculty of Biology, Universitas \\ Gadjah Mada, Jl. Teknika Selatan, Sekip Utara, Yogyakarta 55281, Indonesia;
}

\author{
Article History \\ Received : July 02 $2^{\text {th }}, 2021$ \\ Revised : July $14^{\text {th }}, 2021$ \\ Accepted : July 20 ${ }^{\text {th }}, 2021$ \\ Published : July $26^{\text {th }}, 2021$ \\ *Corresponding Author: \\ Nastiti Wijayanti, \\ Departement of Tropical \\ Biology, Faculty of \\ Biology, Universitas Gadjah \\ Mada, Yogyakarta 55281, \\ Indonesia; \\ Email: \\ nastiti_wijayanti@ugm.ac.id
}

\begin{abstract}
Acacia auriculiformis is a plant which often found in Indonesia. Acacia leaves have been known to have high antioxidant content. The phenolic compound of A. auriculiformis is the largest of these plants and phenolic compound have potential as anticancer protective agents. The aims of this study were to determine the phenolic compound, antioxidant activity, cytotoxic and antiproliferative activity of acacia leaves extract against T47D and MCF-7 breast cancer cell lines. Extraction was carried out by maceration method using methanol as a solvent. Phenolic compounds were examined by Thin Layer Chromatography (TLC) and antioxidant activity was measured using DPPH assay, followed by cytotoxicity and antiproliferation test measured by MTT Assay to obtain the IC50 value and percent of antiproliferation. Based on TLC, A. auriculiformis methanol leaves extract contain a phenolic compound with Rf value of 0.85 compared to gallic acid. Antioxidant activity A. auriculiformis with IC50 value of $9 \mathrm{ppm}$ is classified as high antioxidant activity and MTT assay results for cytotoxicity with IC50 value of 273.8 and $31.26 \mathrm{ppm}$ for T47D and MCF-7 cells, respectively. Antiproliferative analysis also showed high values for MCF-7 cells. These data have shown that methanol leaves extract of A. auriculiformis has high antioxidant activity and inhibited MCF-7 cell proliferation but not T47D breast cancer cell lines.
\end{abstract}

Keywords: Antiproliferation; DPPH; MTT Assay; MCF-7; T47D

\section{Introduction}

Acacia auriculiformis or acacia plants are included in the Fabaceae family and commonly found in Indonesia. Acacia is known to have pharmacological activity as antioxidant, antimicrobial, antimalarial, antimutagen, chemopreventive, spermicidal, hepatoprotective, wound healing and antidiabetic (Rangra et al., 2019). Phenolic is the largest component of these plants containing one or more hydroxyl groups (Singh et al., 2007).

Phenols and polyphenols have a protective mechanism against anticancer by preventing the formation of carcinogens from precursor substances by acting as inhibitor or suppressant. In previous studies, several of Acacia species contain a high phenol and polyphenol compounds and has strong antioxidant and antimutagenic activities (Singh et al., 2007; Kaur et al., 2002). Based on the research conducted by Chew et al (2011) regarding antioxidant activity, it is known that methanol leaves extract of A.auriculiformis has an IC50 value of $161 \pm 30 \mu \mathrm{g} / \mathrm{mL}$ and Sravanthi et al (2014) shown cytotoxic activity (Brine Shrimp Lethality Bio-assay) with IC50 value of $0.55 \mathrm{~g} / \mathrm{mL}$ for the leaves methanol fraction of $A$. Auriculiformis. Another study showed that ethyl acetate bark fraction of A.auriculiformis had an IC50 value of $7.8 \mu \mathrm{g} / \mathrm{mL}$, while the methanol extract of A.auriculiformis leaves had an IC50 value of $7.95 \mathrm{~g} / \mathrm{mL}$ (Rangra et al., 2019). The value of Total Phenolic Compounds (TPC) in A.auriculiformis leaves was $2280 \pm 294 \mathrm{mg}$ 
$\mathrm{GAE} / 100 \mathrm{~g}$ and was included in the medium-low group (Chew et al., 2011).

According to the World Health Organization (WHO), cancer is the second issued that caused death in the world. One of six people die because of cancer and as many as 10 million people die of cancer every year. In 2020, breast cancer is the most common cancer with 2.26 million cases and 685,000 deaths (WHO, 2020). Some breast cancer cells that are often used in research are T47D and MCF-7. Phenol compounds have been reported have antiproliferative activity against the T47D breast cancer cell line. T47D breast cancer cells respond to phenolic compounds by interaction with Aryl hydrocarbon receptor (AhR), inhibition of nitric oxide synthase (NOS) and induction of cell apoptosis through the Fas/FasL pathway (Kampa et al., 2003). Both cells have the ability to express estrogen receptors (ER). MCF-7 has an ER $\alpha$ positive and T47D cells has an ER $\alpha$ and $\beta$ positive (Kampa et al., 2012). This research was conducted to study the antiproliferative effect of Acacia auriculiformis extract on breast cancer cell lines.

\section{Material and Methode}

\section{Acacia Leaf Sample Preparation}

Acacia leaves were taken from the base of leaf twigs number 2-4 as much as $1 \mathrm{~kg}$. Acacia leaves were cleaned and dried in oven at $45^{\circ} \mathrm{C}$. The dried leaves are mashed using blender. Extraction was done by maceration with methanol (1:3) as solvent for three days on shaker at room temperature. Supernatant was filtered using filter paper and then concentrated using a rotary evaporator.

\section{Phenolic Test}

Phenolic content were tested using thin layer chromatography. The stationary phase used silica gel GF 254 while the mobile phase were methanol: acetone: aquadest $(2: 7: 1)$. The extract sample was spotted on a $2 \times 10 \mathrm{~cm}$ silica plate. Gallic acid was used as phenolic standart. The plate sprayed with $\mathrm{FeCl}_{3}$ sprayer reagent. The appearance of the spots were observed with 254 and $366 \mathrm{~nm}$ UV detectors.

\section{Antioxidant Activity Test}

Antioxidant activity was measured by DPPH (Urmi et al., 2013). Concentration of the extract were $100,75,50,25,5$, and $1 \mathrm{ppm}$. One milliliter of each concentration were taken and added with one mililiter of $0.1 \mathrm{mM}$ DPPH then placed in a dark place. The mixture was homogenized by vortex and incubated for 30 minutes. Absorbance was measured with spectrophotometer at $517 \mathrm{~nm}$. The absorbance value calculated by the percent inhibition formula:

$\%$ inhibition $=\frac{\text { abs of DPPH }- \text { abs of sample }}{\text { abs of DPPH }} \times 100 \%$

\section{Cytotoxic Test}

Cytotoxic activity was tested by MTT Assay (CCRC, 2009). Cell was grown on a 96 well plate with $5 \times 10^{4}$ cells/well. Cells were incubated for 24 hours in $5 \% \mathrm{CO}_{2}$ at $37^{\circ} \mathrm{C}$. Cells were treated with different extracts concentrations of 200,100,50, 25, 5, and $1 \mathrm{ppm}$ using DMSO as a solvent. Control cells were prepared with medium containing DMSO. Cells were incubated for 24 hours in $37^{\circ} \mathrm{C}, 5 \% \mathrm{CO}_{2}$. Medium was removed and given by $10 \%$ MTT reagent and incubated at $37^{\circ} \mathrm{C}$ for 4 hours. After 4 hours, 10\% SDS reagent was added to each well and incubated in the dark place overnight. Absorbance was measured using ELISA reader with a wavelenght of $595 \mathrm{~nm}$.

\section{Antiproliferation Test}

Antiproliferation were measured by MTT Assay, in the same condition with cytotoxic test with concentrations 400, 200, 100, 50, and 25 ppm using DMSO as a solvent.

\section{Data Analysis}

The results of thin layer chromatography were analyzed qualitatively by measuring the $\mathrm{Rf}$ value compare to the standart. Antioxidant activity was expressed by IC50 value, the concentration to reduce the initial DPPH concentration by $50 \%$ and cytotoxicity test expressed by IC50 value as an inhibitory of MTT enzymatic activity. While antiproliferation test was expressed by percent of inhibition proliferation inhibition of T47D and MCF-7 cells. 


\section{Results and Discussion}

\section{Detection of phenolic compound using thin} layer chromatography

Thin layer chromatography of $A$. auriculiformis methanol leaves extract using silica gel GF-254 visualization with UV detectors 366 and $254 \mathrm{~nm}$ can be seen in the Figure 1.
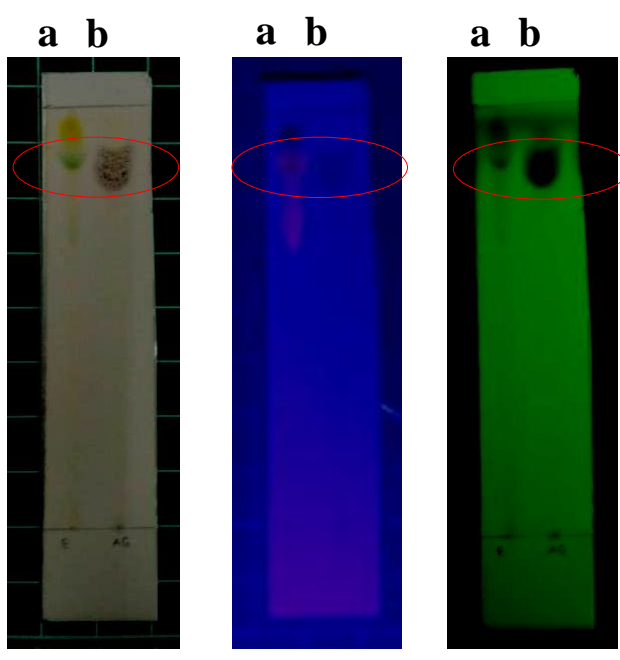
A
B
C

Figure 1. A TLC silica gel plate on which polyphenols analysis; (A) Silica gel plate after sprayed by $\mathrm{FeCl}_{3}$; (B) Silica gel plate on UV $366 \mathrm{~nm}$; (C) Silica gel plate on UV $254 \mathrm{~nm}$; (a) Sample; (b) Standart.

Figure 1A was plate which has been sprayed with $\mathrm{FeCl}_{3}$, the point of separation of phenolic compounds was black-green (a) and point (b) was standard gallic acid which has a black color. Figure 1B showed an orange fluorescent color with a black dot. Figure 1C shows the point of separation of the phenolic compounds which are formed blackish-green color.

\section{Antioxidant potential of phenolic compounds}

The results of the DPPH test on acacia leaves methanol extract with various concentration of $5,25,50,75$, and $100 \mathrm{ppm}$ are shown in Table 1 . The results has been calculated using regression equation between the percentage of inhibition and concentration. The equation give a result as $\mathrm{Y}=0.1997 \mathrm{x}+51.796$ with $\mathrm{R}^{2}=0.9972$ and the IC50 value was 9.00 ppm. Vitamin C used as a standart experiment. The various concentration of vitamin $\mathrm{C}$ were 1 , 2, 4, 6 and $7 \mathrm{ppm}$, the regression equation was calculated as $\mathrm{Y}=3.6379 \mathrm{x}+46.537$ with $\mathrm{R}^{2}=$ 0.9715 and the IC50 of Vitamin C was $0.95 \mathrm{ppm}$.

Table 1. DPPH inhibition and IC50 of $A$. auriculiformis methanol leaves extract and Vitamin $\mathrm{C}$

\begin{tabular}{ccc}
\hline No & $\begin{array}{c}\text { Concentration } \\
(\mathrm{mg} / \mathrm{ml})\end{array}$ & $\begin{array}{c}\text { IC50 } \\
(\mathrm{ppm})\end{array}$ \\
\hline 1 & $\begin{array}{c}\text { Methanol } \\
\text { Leaves Extract } \\
\text { of }\end{array}$ & $9.00 \pm 2.16$ \\
& A.auriculiformis & $\mathrm{Y}=0.1997 \mathrm{x}+51.796$ \\
2 & Vitamin C & $0.95 \pm 0.25$ \\
& & $\mathrm{Y}=3.6379 \mathrm{x}+46.537$ \\
\hline
\end{tabular}

\section{Cytotoxicity activity against MCF7 and T47D cell lines}

Cytotoxicity activity on acacia leaves methanol extract against MCF-7 and T47D cells was shown in Table2.

Table 2. Cytotoxicity of A. auriculiformis methanol leaves extract against MCF7 and T47D cells

\begin{tabular}{ccccc}
\hline \multirow{2}{*}{$\begin{array}{c}\text { Concentration } \\
(\mathrm{ppm})\end{array}$} & \multicolumn{2}{c}{ MCF-7 } & \multicolumn{2}{c}{ T47D } \\
\cline { 2 - 5 } & $\begin{array}{c}\text { \% Cell } \\
\text { viability }\end{array}$ & IC50 & $\begin{array}{c}\text { \% Cell } \\
\text { viability }\end{array}$ & IC50 \\
\hline 400 & 4.99 & & 46.00 & \\
200 & 21.40 & 31.26 & 50.97 & 273.8 \\
100 & 33.69 & \pm & 73.03 & \pm 7.09 \\
25 & 58.15 & 0.39 & 63.89 & \\
5 & 75.54 & & 82.32 & \\
\hline
\end{tabular}

The cytotoxicity test was done for 24 hours. The IC50 value has been calculated using regression equation between log concentration in $\mathrm{x}$-axis and percent of viability in $\mathrm{y}$-axis. These equation give a result in MCF-7 cells as $\mathrm{Y}=$ $36.864 \mathrm{x}+105.11$ with $\mathrm{R}^{2}=0.9814$ and the IC50 value was $31.26 \mathrm{ppm}$, while in T47D cells obtained as $\mathrm{Y}=-19.146 \mathrm{x}+96.681$ $\mathrm{R}^{2}=0.9884$ and the IC50 value was $273.8 \mathrm{ppm}$. 


\section{Antiproliferation activity against MCF7 and T47D cell lines}

Antiproliferation activity was carried out using the MTT assay. The results are shown in a graph of antiproliferation percentage versus concentration as shown in Figure 2.

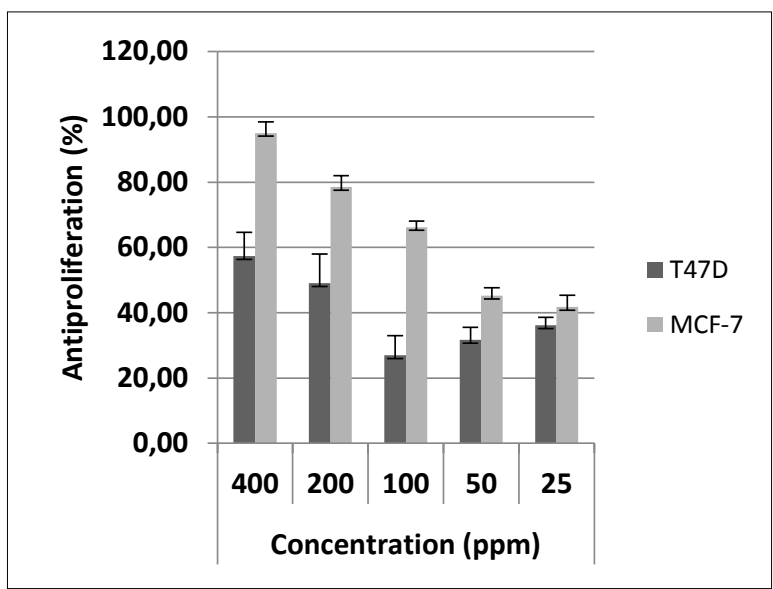

Figure 2. Antiproliferation percent comparison methanol leaves extract of A.auriculiformis against MCF-7 and T47D cells

The proliferative inhibition of $A$. auriculiformis leaves methanol extract was concentration dependent for MCF-7 cell. It has been shown that the extract has different inhibitory mechanisms in different cell types.

\section{Phenolic compound in methanol leaves exctract of Acacia auriculiformis}

Acacia auriculiformis are included in the Fabaceae family with high phenolic content and antioxidant abilities (Singh et al., 2007). Phenols and polyphenols have a protective mechanism against anticancer by preventing the formation of carcinogens from precursor substances by acting as inhibitors or suppressants. In previous studies, several Acacia species have high phenol and polyphenol content and have strong antioxidant and antimutagenic activities (Singh et al., 2004). Many of polyphenolic compounds from plants are reported to contain high antioxidants and able to scavenging free radicals (Ciesla et al., 2012).

Based on the TLC results, methanol leaves extract of A. auriculiformis showed a positive results that contain phenolic compounds after being sprayed by $\mathrm{FeCl}_{3}$. The presence of a phenolic group is indicated by a black-green or dark blue color after being sprayed with $\mathrm{FeCl}_{3}$ (Widyaningrum et al., 2016). Gallic acid was used as a standard phenolic compound. The sample changed color to black-green after being sprayed with $\mathrm{FeCl}_{3}$ and in gallic acid the color changed to black. The separation point of phenol compounds in acacia extract has the same distance as gallic acid. Based on the appearance of the separated compounds, the retention factor (Rf) of methanol leaves extract of $A$. auriculiformis was calculated as 0.85 , while the $\mathrm{Rf}$ value for gallic acid standard was 0.81 . The Rf value between acacia leaves methanol extract and gallic acid has a close Rf value so that can be interpreted that acacia leaves methanol extract contains phenolic compounds.

In this experiment, one point of separation was obtained. This could be due to the solvent from the mobile phase which used, comparison of the solvent and the polarity of the solvent. The solvent used for the mobile phase will affect the relative affinity of the compound for the two phases. Compounds with a high affinity for the stationary phase will move slower, while other compounds will move faster. An experimental thin layer chromatography has a good $\mathrm{Rf}$ value in range betwen 0.2 to 0.8 (Dinakaran et al., 2019).

\section{Antioxidant potential of Acacia auriculiformis methanol leaves extract}

A small IC50 value expressed a strong antioxidant activity in the sample. The IC50 of the acacia leaves methanol extract was higher than vitamin $C$. This indicates that the antioxidant activity of the acacia leaves methanol extract is less weak than vitamin C. Vitamin C is a pure compound while acacia leaves methanol extract was a crude extract, so that acacia leaves extract has a lower antioxidant activity than vitamin C (Amin et al., 2015). The reaction between antioxidant compounds and radicals in DPPH assay caused a color change from purple to yellow. This change is due to a reduction in the double bond in DPPH due to capturing one electron by antioxidant compounds (Rahmayani et al., 2013).

According to Urmi (2013), the highest antioxidant in A. auriculiformis plants is located in the stem by fractionation using ethyl acetate solvent with an IC50 value of $7.80 \mathrm{~g} / \mathrm{ml}$. Meanwhile, the methanol extract of $A$. auriculiformis leaves obtained an IC50 value of $7.95 \mathrm{~g} / \mathrm{ml}$. The IC50 value is slightly lower than 
the data obtained, which is $9 \mathrm{~g} / \mathrm{ml}$. However, both are still at a level with a high antioxidant content.

\section{Cytotoxicity of $A$. auriculiformis methanol leaves extract against MCF7 and T47D cells}

MTT assay is one of the methods used to determine cell viability. In the MTT assay, was generated a linear relationship between living cells and the color result, it make possible to perform an accurate calculations of alteration in cell death rates (Bahaguna et al., 2017). This assay is based on the capacity of the mitochondrial dehydrogenase enzyme in living cells by converting the water-soluble yellow 3 (4,5-dimethylthiazol-2-yl)-2,5-diphenyl tetrazolium bromide (MTT) substrate into watersoluble formazan blue crystals which soluble in water. A live cells are able to change the yellow of MTT to purple-blue and can be dissolved after cell lysis. Meanwhile, dead cells are unable to change MTT, so the formazan blue crystals are not formed (Senthilraja \& Kathiresan, 2015). Based on the cytotoxicity test of acacia leaves methanol extract against MCF-7 and T47D cells, MCF-7 cells has an IC50 31.26 ppm while T47D cells has IC50 273.8 ppm. MCF-7 cells has lower IC50 value than T47D cells. This indicates that A. auriculiformis methanol leaves extract was more toxic to MCF-7 than T47D cells.

\section{Antiproliferation effect of $A$. auriculiformis methanol leaves extract against MCF7}

Antiproliferation test was conducted to determine the ability of the extract to inhibit the proliferative activity of breast cancer cells. Inhibition of MCF-7 cells proliferation was concentration dependent. Inhibition of cell proliferation reached $95.04 \%$ at 400 ppm extract compare with T47D cell which had $57.28 \%$ inhibition at the same concentration.

An extract has a low antiproliferative ability if it has an antiproliferative value lower than $50 \%$, so that the extract has an inactive bioactivity against cells. Meanwhile, an extract has an antiproliferative value between $50-100 \%$, the extract has moderate to strong growth antiproliferative abilities so that the extract has active bioactivity against cells (Sirait et al., 2019).

MCF-7 has estrogen receptor (ER) $\alpha$ positive and T47D cells has ER $\alpha$ and $\beta$ positive (Kampa et al., 2012). These ERs have distict roles in mediating estrogen-dependent growth and differentiation of breast cancer cells (Nassa et al., 2011). These two types of breast cancer cells also have different doubling times. Based on these data, further research on the potential of $A$. auriculiformis methanol leaves extract needs to be done.

\section{Conclusion}

Acacia auriculiformis methanol leaves extract contain a phenolic compounds and has a high antioxidant activity based on DPPH assay. This extract also has a high cytotoxicity and antiproliferation effect against MCF-7 and low in T47D cells. Therefore, this extract is potent to MCF-7 cells but not in T47D cells.

\section{Acknowledgments}

The researcher express deepest gratitude to all who have helped in the completion process research. Also thank you for Gaharu Team Research, Faculty of Biology, Universitas Gadjah Mada for providing cell lines.

\section{References}

Amin, A., Jeanny, W \& Yuniven M.A. (2015). Uji Antioksidan Ekstrak Etanol Klika Faloak (Sterculia quadrifida R.Br) dengan Metode DPPH (2,2-diphenyl-1picrylhydrazyl). Jurnal Fitofarmaka Indonesia, $\quad 2(2)$ : $\quad 111-114$. DOI: http://doi.org/10.33096/jffi.v2i2.180

Bahaguna, A., Imran, K, Viviek, K.B \& Sun C.K. (2017). MTT Assay to Evaluate the Cytotoxic Potential Drug. Bangladesh Journal of Pharmacology, 12:115-118. DOI:http://doi.org/10.3329/bjp.v12i2.308 92

CCRC (2020). Cancer Chemoprevention Research Center Fakultas Farmasi UGM https://ccrc.farmasi.ugm.ac.id/?page id=2 40 (Accessed on July, 1).

Chew, Y.K.L., Chan, E.W.L., Tan, P.L., Lim, Y.Y., Stanslas, J \& Goh, J.K. (2011). Assessment of Phytochemical Content, Polyphenolic Composition, Antioxidant 
and Antibacterial Activities of Leguminosae Medicinal Plants In Peninsular Malaysia. BMC Complementary and Alternative Medicine, 11(12): 1-10.

https://bmccomplementmedtherapies.bio medcentral.com/track/pdf/10.1186/14726882-11-12.pdf

Ciesla, L., Jakub, K, Anna, S, Wieslaw, O \& Monika W.H. (2012). Approach to Develop A Standardized TLC-DPPH Test for Assessing Free Radical Scavenging Properties of Selected Phenolic Compounds. Journal of Pharmaceutical and Biomedical Analysis, 70: 126-135. DOI:https://doi.org/10.1016/j.jpba.2012.0 6.007

Dinakaran, S.K., Chelle, S \& Avasarala, H. (2019). Profiling and Determination of Phenolic Compounds in Poly Herbal Formulations and Their Comparative Evaluation. Journal of Traditional and Complementary Medicine, 9 (4): 319327. DOI:https://doi.org/10.1016/j.jtcme. 2017.12.001

Kampa, M., Alexaki, V.-I., Notas, G., Nifli, A.P., Nistikaki, A., Hatzoglou, A., Bakogeorgou, E., Kouimtzoglou, E., Blekas, G., Boskou, D., Gravanis, A \& Castanas, E. (2004). Antiproliferative and Apoptotic Effects of Selective Phenolic Acids on T47D Human Breast Cancer Cells: Potential Mechanisms of Action. Breast Cancer Research, 6(2): 63-74. doi:10.1186/bcr752

Kampa, M., Notas, G., Pelekanou, V., Troullinaki., Andrianaki, M., Azariadis, K., Kampouri, E., Lavrentaki, K \& Castanas, E. (2012). Early membrane initiated transcriptional effects of estrogen in breast cancer cells: First pharmacological evidence for a novel membrane estrogen receptor element (Erx). $\quad$ Steroids, 77: 959-967. DOI:https://doi.org/10.1016/j.steroids.201 2.02.011
Kaur, K., Arora, S., Hawthorne, M. E., Kaur, S., Kumar, S., \& Mehta, R. G. (2002). A Correlative Study On Antimutagenic And Chemopreventive Activity Ofacacia Auriculiformisa. Cunn. Andacacia Nilotica(L.) Willd. Ex Del. Drug And Chemical Toxicology, 25(1): 39-64. DOI: https://doi.org/10.1081/Dct-100108471

Nassa, G., Tarallo, R., Guzzi, P. H., Ferraro, L., Cirillo, F., Ravo, M., Nola, E., Bauamm, M., Nyman, T.A., Cannataro, M., Ambrosino, C \& Weisz, A. (2011). Comparative analysis of nuclear estrogen receptor alpha and beta interactomes in breast cancer cells. Molecular BioSystem, 7(3): 667-676. DOI:https://doi.org/10.1039/c0mb00145g

Rahmayani, U., Delianis, P \& Ali, D. (2013). Uji Aktivitas Antioksidan Ekstrak Kasar Keong Bakau (Telescopium telescopium) dengan pelarut yang Berbeda terhadap Metode DPPH (Diphenyl Picril Hidrazil). Journal of Marine Research, 2(4):36-45. DOI: https://doi.org/10.14710/jmr.v2i4.36 82

Rangra, N.K., Samanta, S \& Pradhan, K.K. (2019). A Comprehensive Review on Phytopharmacological Investigation of Acacia auriculiformis A.Cunn. ex Benth. Asian Pasific Journal of Tropical Biomedicine, 9(1): 1-1.

DOI:https://doi.org/ 10.4103/22211691.250263

Senthilraja, P \& Kathiresan, K. (2015). In vitro cytotoxicity MTT assay in vero, HepG2 and MCF-7 cell lines study of marine yeast. Journal of Applied Pharmaceutical Sciences, 5(3): 80-84.

DOI:https://doi.org/10.7324/JAPS.2015.5 0313

Singh, R., Singh, S., Kumar, S \& S. Arora. (2007). Evaluation of Antioxidant Potential of Ethyl Acetate Extract/Fractions of Acacia auriculiformis A. Cunn. Food and Chemical Toxicology, 45: 1216-1223. 
DOI:https://doi.org/10.1016/j.fct.2007.01. 002

Sirait, P.S., Setyaningsih, I \& Tarman, K. (2019). Aktivitas antikanker ekstrak Spirulina yang dikulutur pada media walne dan media organik. Jurnal Pengolahan Hasil Perikanan Indonesia, 22(1):50-59.

https://scholar.google.com/scholar?hl=en \&as_sdt=0\%2C $5 \& \mathrm{q}=$ Sirait $\% 2 \mathrm{C}+\mathrm{P} . \mathrm{S} . \% 2$ $\mathrm{C}++$ Setyaningsih\%2C+I+\%26+Tarman\% 2C+K.+\%282019\%29.+Aktivitas+antikan ker+ekstrak+Spirulina+yang+dikulutur $+\mathrm{p}$ ada+media+walne+dan+media+organik.t Jurnal+Pengolahan+Hasil+Perikanan+Ind onesia\%2C+22\%281\%29\%3A+50-

$59 . \& \mathrm{btnG}=$

Sravanthi, S., Santosh, C \& Mohan, M.M. (2014). Phytochemical Analysis, Antioxidant and Antimicrobial Activities of Ethanolic Extract of Acacia auriculiformis. Journal of Applied Environmental and Biological Sciences, 2(1):1-4.

https://web.archive.org/web/2014081610

5213id_http://jeab.scienceresearchlibrary .com:80/admin/uploads/XRZ3s7.pdf

Sweeney, K. J., Swarbrick, A., Sutherland, R. L \& Musgrove, E. A. (1998). Lack of relationship between CDK activity and G1 cyclin expression in breast cancer cells. Oncogene 16,(22): 2865-2878. DOI: https://doi.org/10.1038/sj.onc.12018 14

Urmi, K.F., Syeda, Y.C., Kamal. H., Prabhat, B \& Kaiser, H. (2013). Comparative Antioxidant Activity and Brine Shrimp Lethality Bioassay of Different Parts of The Plant Acacia auriculiformis. International Journal of Pharmaceutical Sciences and Research, 4(2): 872-877. https://www.researchgate.net/profile/Kais er-

Hamid/publication/265810287_Comparat ive_antioxidant_activity_and_brine_shri mp_lethality_bioassay_of_different_parts _of_the_plant-

Acacia auriculiformis/links/541c38110c
f203f155b36e67/Comparativeantioxidant-activity-and-brine-shrimplethality-bioassay-of-different-parts-ofthe-plant-Acacia-auriculiformis.pdf

WHO (2020). Breast Cancer. https://www.who.int/news-room/factsheets/ Accessed on 29 April 2021.

Widyaningrum, N.R., Anom, P \& Widhi, W. (2016). Profil Kromatografi Lapis Tipis Ekstrak Etanol Daun Talok (Muntingia calabura L) beserta Potensinya sebagai Pereda Nyeri. Indonesian Journal on Medical Science, 3(1): 105-114. http://ejournal.ijmsbm.org/index.php/ijms /article/view/74 